\title{
Effectiveness of clinical surface cleaning and disinfection: evaluation methods
}

\author{
Eficiência da limpeza e desinfecção de superfícies clínicas: métodos de avaliação \\ Eficiencia de la limpieza y desinfección de superficies clínicas: métodos de evaluación
}

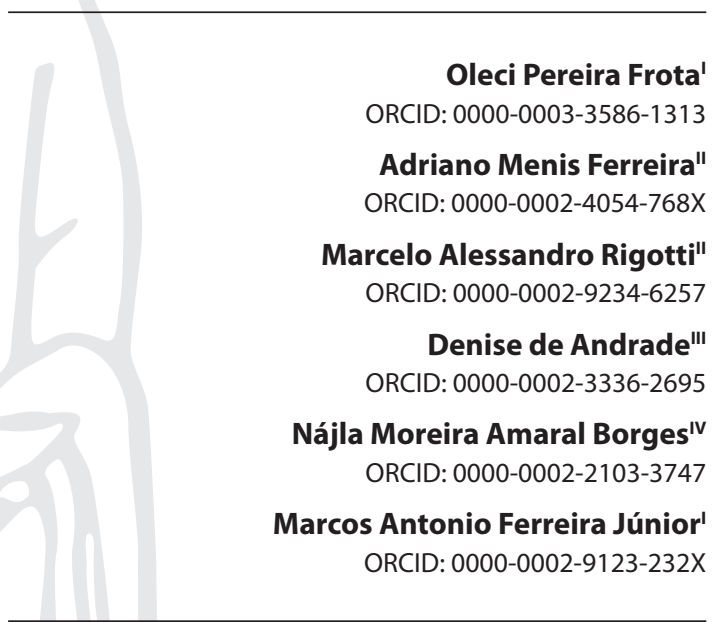

' Universidade Federal de Mato Grosso do Sul. Campo Grande, Mato Grosso do Sul, Brazil.

"Universidade Federal de Mato Grosso do Sul. Três Lagoas, Mato Grosso do Sul, Brazil.

II' Universidade de São Paulo. Ribeirão Preto, São Paulo, Brazil. " Prefeitura Municipal de Campo Grande. Campo Grande, Mato Grosso do Sul, Brazil.

How to cite this article: Frota OP, Ferreira AM, Rigotti MA, Andrade D, Borges NMA, Ferreira Jr MA. Effectiveness of clinical surface cleaning and disinfection: evaluation methods.

Rev Bras Enferm. 2020;73(1):e20180623. doi: http://dx.doi.org/10.1590/0034-7167-2018-0623

Corresponding Author:

Oleci Pereira Frota

E-mail: olecifrota@gmail.com

EDITOR IN CHIEF: Antonio José de Almeida Filho ASSOCIATE EDITOR: Hugo Fernandes

\section{ABSTRACT}

Objective: To discuss the methods employed to evaluate the effectiveness of clinical surface cleaning and disinfection (C\&D). Method: This is a theoretical reflection based on scientific studies and the experience of the authors. Knowledge and current gaps, the need for further studies, and practical application of the methods were approached. Results: There are four main methods used to evaluate the effectiveness of clinical surface C\&D: visual inspection, fluorescent markers, microbiological cultures, and adenosine triphosphate (ATP) bioluminescence. The first two are used to evaluate the process and to predict adherence to protocols by the staff, and the last two are employed to evaluate the results, therefore being the most relevant to assess the risk of infection. Final considerations: The ideal method was not found, because all of them showed limitations. There is a need for strategies to optimize the precision of these methods.

Descriptors: Cross Infection; Equipment Contamination; Housekeeping, Hospital; Disinfection; Process Assessment (Health Care).

\section{RESUMO}

Objetivo: Discutir os métodos empregados para avaliar a eficiência da limpeza e desinfecção (L\&D) de superfícies clínicas. Método: Trata-se de uma reflexão teórica fundamentada em estudos científicos e experiência dos autores. Foram abordados o conhecimento e as lacunas atuais, a necessidade de futuras investigações e a prática na utilização dos métodos. Resultados: São quatro os principais métodos utilizados para avaliar a eficiência da L\&D de superfícies clínicas: inspeção visual, marcadores fluorescentes, culturas microbiológicas e teste de adenosina trifosfato por bioluminescência. Os dois primeiros são utilizados para avaliar o processo e preveem a adesão aos protocolos pela equipe, enquanto os dois últimos são empregados para avaliar os resultados, portanto, mais relevantes na avaliação do risco de infecção. Considerações finais: Não foi encontrado um método ideal, pois todos apresentaram limitações. São necessárias estratégias que potencializem a precisão desses métodos.

Descritores: Infecção Hospitalar; Contaminação de Equipamentos; Serviço Hospitalar de Limpeza; Desinfecção; Avaliação de Processos (Cuidados de Saúde).

\section{RESUMEN}

Objetivo: Discutir los métodos utilizados para evaluar la eficiencia de la limpieza y desinfección (L\&D) de superficies clínicas. Método: Reflexión teórica fundamentada en estudios científicos y en la experiencia de los autores. Fueron abordados el conocimiento y las carencias presentes, la necesidad de investigaciones futuras y la práctica en la aplicación de los métodos. Resultados: Los métodos más habitualmente aplicados para evaluar la eficiencia de la L\&D de superficies clínicas son cuatro: inspección visual, marcadores fluorescentes, cultivos microbiológicos y test de adenosina trifosfato por bioluminiscencia. Los dos primeros son utilizados para evaluar el proceso. Prevén la adhesión a los protocolos por parte del equipo. Los dos últimos son aplicados para evaluar los resultados, por lo cual son más relevantes para descubrir riesgos de infección. Consideraciones finales: No se encontró el método ideal, dado que todos presentan limitaciones. Se necesitan estrategias que optimicen la precisión de estos métodos.

Descriptores: Infección Hospitalaria; Contaminación de Equipos; Servicio de Limpieza en Hospital; Desinfección; Evaluación de Proceso (Atención de Salud). 


\section{INTRODUCTION}

Over the past years, a step forward has been taken with discussions and studies by researchers, health institutions, and organizations regarding the role facilities play on the incidence of healthcare-associated infections (HAI)(1). As a result of the growing body of evidence linking facilities with HAI transmission, greater attention has been given to sanitation and forms to improve the effectiveness of clinical surface cleaning and disinfection (C\&D) practices, with an aim at reducing cross infection ${ }^{(2)}$.

Even with proper hand hygiene, C\&D measures have shown some flaws. As professionals touch contaminated surfaces near patients, the hygiene effect may be invalidated by transferring pathogens from one patient to the next, which leads to the occurrence of HAl, thus increasing morbidity-mortality rates, hospital stay, and additional costs with material and human resources.

Studies have demonstrated that there is greater risk of $\mathrm{HAI}$ when patients use beds that were previously occupied by patients who were colonized or infected by healthcare-associated pathogens, such as methicillin-resistant Staphylococcus aureus (MRSA), Clostridium difficile, Vancomycin-resistant Enterococcus (VRE), and multidrug-resistant Gram-negative (MDRGN) agents. These agents often contaminate clinical surfaces near patients and may lead to the transmission of pathogens, representing a primary source of contamination for health professionals' hands and/or gloves ${ }^{(3-4)}$.

Currently, there are many unanswered, controversial or conflicting questions about $\mathrm{C} \& \mathrm{D}$ regarding strategies for $\mathrm{HAl}$ control compared to other actions, such as patient monitoring, use of isolation, hand hygiene, and antimicrobial regimen. The evidence is still incipient and lacks qualitative and quantitative improvements. The consensus is that the C\&D process is subject to discussion on its rules, rates and, most importantly, procedures, equipment, and benchmark related to quantitative monitoring methods for surface $C \& D^{(5)}$.

Healthcare facilities are often evaluated only by visual inspection, which may meet the aesthetic parameters, but cannot avoid risk of infection for patients. Therefore, the Centers for Disease Control and Prevention $(C D C)^{(6)}$ and the Brazilian Health Regulatory Agency (ANVISA, as per its acronym in Portuguese) ${ }^{(7)}$ started to recommend that hospitals assure proper procedures for surface $C \& D$ and carry out continuous monitoring to guarantee the quality of their procedures. However, it is not clear which methods are ideal for the monitoring, and there was no specification on how this is supposed to be achieved ${ }^{(2-3,8)}$.

\section{OBJECTIVE}

To discuss the methods employed to evaluate the effectiveness of clinical surface C\&D.

\section{METHOD}

This theoretical and reflective study was based on scientific articles published in journals indexed in the Virtual Health Library (VHL), the US National Library of Medicine (PubMed), Scopus, and the Web of Science databases. The basic database form was used for the following search strategy: "Method *" AND (Evaluate* OR Assessment) AND (Clean* OR Disinfecti*) AND (Environment* OR Clinical surfaces). Titles and abstracts of the resulting articles were read to select the most relevant, in which 10 were elected by consensus among three researchers for critical analysis, reflection, and text design.

The analysis showed four main methods used to evaluate the effectiveness of C\&D in healthcare institutions: visual inspection, fluorescent markers, microbiological cultures, and ATP bioluminescence ${ }^{(1-2,5,9-15)}$. A synoptic chart was created to extract the following aspects for reflection: principles, indications, operation, benchmark (cut-off point), effectiveness, and advantages and disadvantages of the methods. Based on the synoptic chart, the reflective text was designed.

\section{RESULTS}

There are currently four main methods used to evaluate the effectiveness of clinical surface C\&D: visual inspection, fluorescent markers, microbiological cultures, and ATP bioluminescence. The first two are used to evaluate the process and to predict adherence to protocols by the staff, whereas the last are employed to evaluate the results, therefore being the most relevant to assess the risk of infection

\section{DISCUSSION}

\section{Visual inspection}

The visual inspection of healthcare facilities is the most commonly used method worldwide to evaluate the effectiveness of C\&D. $(2,4,10,12)$ It detects gross practice flaws, such as visible dirt, dust, waste, stains - including from patches - cracks on surfaces, and humidity. ${ }^{(2,10,12)}$ Therefore, it helps to evaluate individual performance of the janitorial staff. Nevertheless, it has been well documented that visual assessment is a poor indicator because of the subjective characteristics from each evaluator related to what is cleaned or dirty ${ }^{(2,12)}$. In addition, the professional that performs the inspection often tends to concentrate in some areas, such as floors and walls, which have limited relevance in the transmission of pathogen $s^{(2,10)}$.

Studies have reported that subjective (visual inspection) and objective (ATP bioluminescence, aerobic culture, fluorescent markers) analyses - when carried out prior and after a routine cleaning protocol - are capable of demonstrating a significant increase in the proportion of surfaces that are considered cleaned, after the protocol implementation ${ }^{(3,12)}$. However, there is evidence that visual inspection, when performed separately, increases significantly the proportion of surfaces considered cleaned, even after terminal cleaning ${ }^{(1,4,9,11)}$. A study that assessed 124 articles identified that 17 to $93 \%$ more surfaces were considered "cleaned" by visual inspection compared to other evaluation methods ${ }^{(8)}$.

This finding may be explained by the high sensitivity (95\%) and very low specificity (9\%) of visual inspection, when compared to aerobic culture as a "reference" ${ }^{\prime \prime 3,12)}$. In short, visual inspection alone can be a poor indicator of $C \& D$ quality, because more contaminated surfaces may be classified as cleaned ${ }^{(10-11)}$. The 
use of other methods, such as fluorescent markers or ATP bioluminescence, provides a slight increase in specificity, but with a decrease in sensitivity ${ }^{(10)}$. Therefore, visual evaluation of surfaces proved to be less reliable for monitoring surface $C \& D$, when the comparison to quantitative methods to document the results of this practice becomes relevant ${ }^{(11)}$.

\section{Fluorescent markers}

In recent years, fluorescent gels, powders, and lotions were developed to mark objects submitted to cleaning. As a result of severe limitations in the last two years related to scattering (powders) and removal (lotion, when submitted to dry air), there are few or no experience published on the application of these methods as monitoring strategies for sanitation practices in hospital settings ${ }^{(10)}$.

In contrast, fluorescent gels have been widely used to evaluate the quality of cleaning. This method involves the application of an invisible gel, which quickly dries in contact with the surface and is resistant to dry friction, but can be easily removed with friction if wet. The gel is visible only through ultraviolet (UV) light, thus, cleaning precision is assessed by applying UV light on the areas where the gel was applied before cleaning ${ }^{(6)}$. Studies carried out with this method reported recurrent practice flaws during surface $C \& D^{(11,13)}$.

In short, the fluorescent gel is used to indicate the physical removal of a given substance applied. Additionally, when it is inspected by UV light, the lack of stains indicates that sufficient friction was applied to the cleaning ${ }^{(4)}$, but this does not guarantee that the surface is microbiologically safe, since the method is unable to detect microorganisms. Therefore, the results must be interpreted with caution, because surfaces that are effectively disinfected, but less effectively cleaned, may be labeled as dirty and vice-versa ${ }^{(6)}$; thus, its use during outbreaks must be adjuvant.

\section{Microbiological cultures}

Microbial culture methods have been widely used to evaluate the contamination of hospital facilities in different studies ${ }^{(2,6,8-13)}$. In modern hospitals, samples of target surfaces (mattresses, stethoscopes, toys, etc.) have been studied applying culture techniques. The method consists of obtaining samples potentially impregnated by microorganisms submitted to culture medium with favorable conditions for their growth (substrate, $\mathrm{pH}$, oxygenation, water $)^{(3,10,12)}$.

Culture results are expressed as colony forming units (CFU) of total aerobics ${ }^{(2,12)}$ or specific microorganisms, such as S. aureus ${ }^{(10)}$ and C. difficile ${ }^{(4,11)}$. This kind of investigation is generally recommended only as part of an epidemiological investigation, with ongoing outbreaks, as a research study, or as part of the evaluation process or policy ${ }^{(12)}$, since the time needed to count the colonies and to identify the pathogens may take at least two days, apart from being expensive ${ }^{(11,13)}$.

Cultures provide the most precise indication for risk of infection, because they are able to detect and quantify a wide range of viable microorganisms. Microbiological methods can produce results with high specificity, sampling techniques provide varied sensitivity, and often underestimate the bioburden on a surface, which hinders a precise evaluation of surface contamination in terms of comparability ${ }^{(2,6)}$. However, it is a user-friendly method applied by several institutions, including the food industry and, most recently, hospitals.

The most frequently cut-off point used in the studies for surface approval is $<2.5 \mathrm{UFC} / \mathrm{cm}^{2}$ for aerobic colony count ${ }^{(2,4,6,11-13)}$ and $<1 \mathrm{UFC} / \mathrm{cm}^{2}$ for hospital pathogens (MRSA, VRE, C. difficile, etc.) (5). However, there is not yet a universally accepted benchmark, given that the studies use other benchmarks, such as $5 \mathrm{UFC} / \mathrm{cm}^{2}$, and methodologies vary considerably ${ }^{(9-13)}$.

The most reliable indicator of environmental hygiene for healthcare facilities is the presence of coagulase-positive Staphylococcus, since it survives for months on hospital surfaces. ${ }^{(10)}$ Studies that investigate the application of microbiological guidelines in healthcare units have used both S. aureus and MRSA to help monitoring the $C \& D^{(5,10)}$.

\section{Adenosine triphosphate bioluminescence}

Adenosine triphosphate is the main energy carrier of all human beings. Its presence in the cells is a strong indicator of living organisms ${ }^{(4,14)}$. ATP bioluminescence is a method that measures the quantity of organic ATP present in a sample. Using a specific swab, the organic matter present on the surface is collected and transferred to a detection device that is made up of an enzyme substrate compound (luciferin-luciferase). The reaction formed by contact of the sample with this compound releases a type of light, similar to what happens with a firefly, and its intensity is measured by portable luminometers that show the result in relative light units (RLU). The quantity of RLU is proportional to the quantity of ATP, which in its turn is proportional to the density of the organic matter ${ }^{(1,4)}$.

This method has become popular, but there are still controversial issues ${ }^{(2,11,13)}$ and limitations (Table 1 ), which require robust investigations. Depending on the luminometer brand or model and setting to be monitored, the benchmark of ATP bioluminescence systems may vary considerably. In healthcare units, reference levels vary considerably from 25 to $500 \mathrm{RLU}$ per 10 to $100 \mathrm{~cm}^{2}$ of surface ${ }^{(5)}$. This variation is due to the wide range of commercialized devices, systems, and reagents ${ }^{(6)}$. The benchmarking must be specific, according to local characteristics related to room temperature, humidity, nature of the surface, type and level of association with the organic matter, risk of infection in the unit, local pathogenic epidemiology, and presence of outbreaks ${ }^{(4)}$.

It is important to measure ATP 10 minutes after cleaning with detergent or disinfectant. This procedure allows complete surface drying, and prevents alterations in RLU readings due to the contact between sanitizing and reagents. Even so, the correlation between ATP levels and microbial contamination is unknown ${ }^{(2,10,12-13)}$. Additional investigations are necessary to determine the threshold for the ideal ATP value, in order to define whether a given surface is properly cleaned ${ }^{(15)}$, and with the challenge of correlating the value with a decrease in infections. The sensitivity and specificity of the luminometers or trial systems may differ significantly, such as chemical reactions, light detection systems, among others ${ }^{(11)}$. 
Similar to the fluorescent gel, and due to the great amount of microbial ATP of unknown origin on surfaces, ATP readings on surfaces that are properly disinfected, but less properly cleaned, may be more frequently disapproved when compared to culture techniques ${ }^{(6)}$. Regardless of whether a considerable variation may occur between readings and the sensitivity of the systems commercially available, very low readings are typically associated with low aerobic colony counts on surfaces ${ }^{(10)}$. Currently, there are systems already available that measure ATP of microbial origin only.

ATP reading may be jeopardized by several factors, such as the presence of residual detergents or disinfectants, such as sodium hypochlorite, which is contraindicated for ATP measuring, including corroded surfaces, plasticizers found in microfiber cloths or ammonium compounds found in laundry products ${ }^{(5,8)}$. The attempt to correlate RLU with the amount of microorganisms on surfaces has been widely discussed among researchers to try to standardize the ATP bioluminescence method as a replacement to other methods. However, this issue is controversial, because the presence of ATP is conditioned to the amount of animal or vegetal organic matter and not necessarily of microorganisms. Therefore, the lack of a correlation or a poor correlation between RLU and the presence of microorganisms may be due to several factors, such as variations on the size and type of microbial cells and in their development stage ${ }^{(14)}$. The main advantages and disadvantages of the four methods used to evaluate surface C\&D practices are summarized in Chart 1.

\section{Study limitations}

There are few or no studies correlating quantitative and qualitative data from methods of evaluation of the effectiveness of clinical surface $C \& D$ with results for health care, including infection-association health care. Therefore, this study provides resources for choosing methods and strategies for monitoring the quality of surface $C \& D$. Clinical trials must be carried out to determine the best indications (outbreak, routine, research, etc.) for these methods, as well as their cost-benefit, and respective impacts on healthcare indicators.

\section{Contributions of this reflective paper for the nursing area}

Since clinical surface C\&D is assigned to the nursing staff in most healthcare facilities in Brazil and worldwide, and its evaluation is mostly carried out by visual inspection, this study helps to define and analyze the methods and breakthrough technologies currently available to evaluate the impact these practices have on the microbiological safety of clinical surfaces. Although it is not a panacea, it serves as a resource (i) to stimulate formal teaching of this underrated practice in healthcare facilities, (ii) to boost the management of material (planning, decision-making, method selection, and technologies) and human (ongoing education) resources, (iii) to stimulate the development of robust clinical research, and (iv) to promote guidance for the healthcare practice. Finally, this study contributes to the understanding that

Chart 1 - Summary of the main advantages and disadvantages of the methods used to evaluate cleaning and disinfection practices in healthcare facilities

\begin{tabular}{|c|c|c|}
\hline Method & Advantages & Disadvantages \\
\hline Visual inspection & $\begin{array}{l}\text { - Simple }{ }^{(8,16)} \\
\text { - Cheap }{ }^{(8,16)} \\
\text { - User-friendly for large areas (wards, rooms) }{ }^{(8)} \\
\text { - May be implemented with minimum training }{ }^{(8)} \\
\text { - Possible benchmarking }{ }^{(8)}\end{array}$ & $\begin{array}{l}\text { - Unreliable measure for C\&D* quality }{ }^{(16)} \\
\text { - Subjective } \\
\text { - Does not evaluate bioburden }^{(8)} \\
\text { - Does not correlate with bioburden } \\
\text { - May be mistaken with disorder and odors }\end{array}$ \\
\hline Fluorescents markers & $\begin{array}{l}\text { - Quick, objective, and cheap } \\
\text { - Minimum training required } \\
\text { - Minimum equipment required } \\
\text { - }{ }^{(16)} \\
\text { - Provide immediate feedback }{ }^{(8)} \\
\text { - May improve the quality of the practices }{ }^{(16)} \\
\text { - Possible benchmarking(8) }\end{array}$ & $\begin{array}{l}\text { - Tricky, since there is a need to mark the surfaces blindly } \\
\text { before cleaning, without the staff knowing the defined } \\
\text { areas, and to check them after cleaning with UV light }{ }^{(8,16)} \\
\text { - Do not evaluate bioburden }{ }^{(8)} \\
\text { - Emphasis on easily visible surfaces and not heavily } \\
\text { touched }^{(8)}\end{array}$ \\
\hline Microbiological cultures & $\begin{array}{l}\text { - Objective } \\
\text { - Relatively simple } \\
\text { - Provide quantitative data(8) } \\
\text { - High sensitivity and } \text { specificity }^{(8)} \\
\text { - Identify traced pathogens }{ }^{(8,14)} \\
\text { - May suggest or confirm environmental reservoirs and/ } \\
\text { or sources of outbreak }^{(8)}\end{array}$ & $\begin{array}{l}\text { - Expensive }{ }^{(8,16-17)} \\
\text { - Require, at least, 24-48h to provide results }{ }^{(8,16-17)} \\
\text { - Tricky }{ }^{(17)} \text { and require a microbiology lab }{ }^{(16)} \\
\text { - Require accessible lab resources and specialized } \\
\text { personnel to interpret the results }{ }^{(8)} \\
\text { - Routine use unadvisable in local and international } \\
\text { guidelines }{ }^{(8)} \\
\text { - Risk of infection depends on standardized } \\
\text { benchmarking } \\
\text { - Sample of small surface area only }{ }^{(8)}\end{array}$ \\
\hline $\begin{array}{l}\text { Adenosine triphosphate } \\
\text { bioluminescence }\end{array}$ & $\begin{array}{l}\text { - Quick }{ }^{(8,16)} \\
\text { - Objective } \\
\text { - Minimum training required } \\
\text { - Provides quantitative measurement of the C\&D*(16) } \\
\text { - Provides immediate feedback } \\
\text { - May improve the practices }{ }^{(16)}\end{array}$ & $\begin{array}{l}\text { - Expensive } \mathrm{e}^{(8,16)} \\
\text { - Requires luminometers and swabs }{ }^{(16)} \\
\text { - Propensity to false-positive results of given systems }{ }^{(8)} \\
\text { - Low sensitivity and specificity }{ }^{(8,18)} \\
\text { - Trials currently non-standardized }{ }^{(8,18)} \\
\text { - Variable cut-off point }^{(8,18)} \\
\text { - Technology under development }^{(8,18)} \\
\text { - Does not identify pathogen }\end{array}$ \\
\hline
\end{tabular}


surface C\&D goes much further than meeting mere aesthetic obligations, considering that it is an important variable related to patient safety.

\section{FINAL CONSIDERATIONS}

The ideal C\&D method should be able to determine whether a surface was cleaned, taking into account the levels of organic matter and microorganisms present, the risk of infection, the presence of MDR pathogens, as well as being cost-effective, replicable, user-friendly, and quick. Therefore, the development of new technologies and innovations is strongly recommended, such as the improvement of monitoring methods for surface C\&D in healthcare services.

The prevention of pathogen transmission is unquestionably one of the major challenges of this new millennium. One to the main strategies to overcome this challenge is the maintenance of the surfaces of facilities in proper sanitary conditions to limit the spread of pathogens and/or the acquisition of antimicrobial resistance. There is still a lot to improve, but at least there are alternative methods to visual inspection already available to evaluate the effectiveness of C\&D.

\section{FUNDING}

The Foundation for Support to the Development of Education, Science, and Technology of the State of Mato Grosso do Sul (FUNDECT) for the Brazilian Unified Health System (SUS) - Edict FUNDECT/DECIT-MS/CNPq/SES, agreement 04/2013 PPSUS-MS, protocol no. 26434.386.4552.26042013, (FUNDECT; research funding) and Coordination for the Improvement of Higher Education Personnel (PhD scholarship of the first author).

\section{REFERENCES}

1. Hardy K, Abbott G, Bashford S, Bucior H, Codd J, Holland M, et al. Can measuring environmental cleanliness using ATP aid in the monitoring of wards with periods of increased incidence of Clostridium difficile? J Infect Prev. 2014;15(1):31-5. doi: 10.1177/1757177413501568

2. Frota OP, Ferreira AM, Koch R, de Andrade D, Rigotti MA, Borges NM, Almeida MT. Surface cleaning effectiveness in a walk-in emergency care unit: influence of a multifaceted intervention. Am J Infect Control [Internet]. 2016[cited 2017 Jan 16];44(12):1572-7. Available from: https:// www.ncbi.nlm.nih.gov/pubmed/27566877

3. Luick L, Thompson PA, Loock MH, Vetter SL, Cook J, Guerrero DM. Diagnostic assessment of different environmental cleaning monitoring methods. Am J Infect Control [Internet]. 2013[cited 2016 Sep 15];41(8):751-2. Available from: https://www.ncbi.nlm.nih.gov/ pubmed $/ 23380380$

4. Gordon L, Bruce N, Suh KN, Roth V. Evaluating and operationalizing an environmental auditing program: a pilot study. Am J Infect Control [Internet]. 2014[cited 2016 Aug 08];42(7):702-7. Available from: https://www.ncbi.nlm.nih.gov/pubmed/24969123

5. Dancer SJ. Controlling hospital-acquired infection: focus on the role of the environment and new technologies for decontamination. Clin Microbiol Rev [Internet]. 2014[cited 2016 Aug 08];27(4):665-90. Available from: https://www.ncbi.nlm.nih.gov/pubmed/25278571

6. Guh A, Carling P, Environmental Evaluation Workgroup. Options for Evaluating Environmental Cleaning. Atlanta, GA: Centers for Disease Control and Prevention [Internet]. 2010[cited 2016 Aug 08]. http://www.cdc.gov/HAl/pdfs/toolkits/Environ-Cleaning-Eval-Toolkit12-2-2010.pdf

7. Agência Nacional de Vigilância Sanitária-Anvisa (BR). Segurança do paciente em serviços de saúde: limpeza e desinfecção de superfícies. Brasília: Anvisa; 2012.

8. Mitchell BG, Wilson F, Dancer SJ, McGregor A. Methods to evaluate environmental cleanliness in healthcare facilities. Healthc Infect [Internet]. 2013[cited 2016 Apr 16];18(1):23-30. Available from: http://www.publish.csiro.au/hi/HI12047

9. Cloutman-Green E, D'Arcy N, Spratt DA, Hartley JC, Klein N. How clean is clean--is a new microbiology standard required? Am J Infect Control [Internet]. 2014[cited 2016 Aug 18];2(9):1002-3. Available from: https://www.ncbi.nlm.nih.gov/pubmed/25179334

10. Ferreira AM, Andrade D, Rigotti MA, Almeida MTG, Guerra OD, Santos Jr AG. Assessment of disinfection of hospital surfaces using different monitoring methods. Rev Latino-Am Enfermagem [Internet]. 2015[cited 2016 Jan 23];23(3):466-74. Available from: http://www.scielo.br/ $\mathrm{pdf} / \mathrm{rlae} / \mathrm{v} 23 \mathrm{n} 3 / 0104-1169-$ rlae-23-03-00466.pdf

11. Leas BF, Sullivan N, Han JH, Pegues DA, Kaczmarek JL, Umscheid CA. Environmental Cleaning for the Prevention of Healthcare-Associated Infections. Technical Brief No. 22 (Prepared by the ECRI Institute - Penn Medicine Evidence-based Practice Center under Contract No. 290-2012-00011-I.) AHRQ Publication No. 15-EHC020-EF [Internet]. Rockville, MD: Agency for Healthcare Research and Quality; August 2015[cited 2016 Jan 23]. Available from: http://www.ncbi.nlm.nih.gov/books/NBK311016/pdf/Bookshelf_NBK311016.pdf

12. Frota OP, Ferreira AM, Guerra OG, Rigotti MA, Andrade D, Borges NMA, et al. Efficiency of cleaning and disinfection of surfaces: correlation between assessment methods. Rev Bras Enferm [Internet]. 2017[cited 2018 Mar 10];70(6):1176-83. Available from: http://www.scielo.br/pdf/ reben/v70n6/0034-7167-reben-70-06-1176.pdf

13. Santos-Jr AG, Ferreira AM, Frota OP, Rigotti MA, Barcelos LS, Sousa AFL, et al. Effectiveness of surface cleaning and disinfection in a Brazilian healthcare facility. Open Nurs J [Internet]. 2018[cited 2018 Mar 10];12:36-44. Available from: https://www.ncbi.nlm.nih.gov/ pubmed/29643951.

14. Shama G, Malik DJ. The uses and abuses of rapid bioluminescence-based ATP assays. Int J Hyg Environ Health [Internet]. 2013 [cited 2016 Sep 15];216(2):115-25. Available from: https://www.ncbi.nlm.nih.gov/pubmed/22541898 
15. Huang YS, Chen YC, Chen ML, Cheng A, Hung IC, Wang JT, et al. Comparing visual inspection, aerobic colony counts, and adenosine triphosphate bioluminescence assay for evaluating surface cleanliness at a medical center. Am J Infect Control [Internet]. 2015[cited 2016 Mar 10];43(8):882-6. Available from: https://www.ncbi.nlm.nih.gov/pubmed/25952617

16. Havill NL. Best practices in disinfection of noncritical surfaces in the health care setting: creating a bundle for success. Am J Infect Control [Internet]. 2013[cited 2017 Mar 8];41(5 Suppl):S26-30. Available from: https://www.ncbi.nlm.nih.gov/pubmed/23622744

17. Smith PW, Sayles H, Hewlett A, Cavalieri RJ, Gibbs SG, Rupp ME. A study of three methods for assessment of hospital environmental cleaning. Healthc Infect. 2013;18(25):80-5. doi: 10.1071/HI13001

18. Carling PC, Parry MF, Bruno-Murtha LA, Dick B. Improving environmental hygiene in 27 intensive care units to decrease multidrugresistant bacterial transmission. Crit Care [Internet]. 2010[cited 2017 Apr 12];38(4):1054-9. Available from: https://www.ncbi.nlm.nih.gov/ pubmed/20081531 